II. МОЛОДI НАУКОВЦІ

\title{
TERRITORY, PLACE, SCALE, AND POLARIZATION OF ELECTORAL PREFERENCES IN UKRAINE, 2002-2014
}

\begin{abstract}
Nationalization of the party system and electorates not obviously results in the territorial homogenization of voting behavior or shifts from the territorial to functional cleavages. Elections outcomes in Ukraine are broadly analyzed from the perspective of regional divisions, compositional effects, cleavages, and polarization of political beliefs. However, we assume that spatiality of electoral behavior in Ukraine is more complex and might be better understood from the perspective of the TPSN framework intertwined and mutually constitutive effects of territory $(T)$, place $(P)$, scale $(S)$ and networks $(N)$. The paper aims to analyze territorial homogenization, heterogeneity, and polarization of electoral behavior in Ukraine using data at polling stations level for 2002-2014 parliamentary elections. We use Lee index (the analysis of variance using mean absolute deviation divided by two to avoid double counting) to analyze territorial homogenization. The study reveals that in 2002-2014 Ukraine was continually territorially homogenized, while, at the same time, territorially polarized - national territorial homogenization index was decreasing (higher homogenization), while the index for particular regions (Galicia and Donbas) was permanently high (higher polarization) in 2002-2012 for Galicia and in 2006-2014 for Donbas oblasts. The cartographic analysis reveals that electoral behavior patterns and territorial polarization often follow administrative borders (oblast or rayon level) as well as historical borders (the interwar border between USSR and Poland and the border between Austrian and Russian empires). Analysis of Manafort trial court documents also reveals strategic deployment of geographical scale by Party of Regions. Despite being empirically very limited, this study shows that mutual effects of bounded territories, place contexts, scale, and networks are crucial for the understanding how parties territorially structure Ukraine.
\end{abstract}

Keywords: territorial homogeneity, territorial polarization, politics of scale, parliamentary elections in Ukraine.

Introduction. Not all newly emerged as well as established democracies have patterns of territorial homogenization of voting behavior in the process of nationalization of electorates and party systems. Communication technologies were gradually creating opportunities to reach the whole national population and preconditions for the diminishing of spatial differences in political beliefs. However, as overwhelming geographical research shows, regional and local contexts, geographical distance and existing and phantom borders are still essential for the understanding of elections outcomes. Moreover, social media can cause polarization of political beliefs (Bail et al., 2018; Bernhardt, Krasa, \& Polborn, 2008; Prior, 2013; Tucker et al., 2018). It can be manifested in electoral preferences and may have territorial dimension. Moreover, Wing and Walker (2010) argue that geography is central to electoral polarization in the United States, Johnston and Others (2004) and McAllister and Studlar (1992) reveal regional polarization of electoral preferences in the United Kingdom, and Ferreira Do Vale (2015) shows that Brazil was also polarized along regional divisions in 2014 elections. Therefore, in contrast to the nationalization of party systems and territorial homogenization hypotheses, territorial polarization is still in question for new and established democracies.

Polarization is also about cleavages, and each party that wants to remain at political arena should crystalize cleavage in society to mobilize electorate along its lines (Lipset \& Rokkan, 1967). Cleavages (as well as polarization) could follow territorial or functional lines in Lipset and Rokkan model; however, they are not strictly located in one pole of the divide. While cleavages along the territorial axis are geographical in their nature and, in Lipset and Rokkan theory, are about center-periphery relations, cleavages along the functional line (ideology or economic interests) may also have geographical patterns of manifestation in the political system (for example, the geography of uneven development). Maggini and Emanuele (2015) study of the nationalization of electorates and party systems in Europe reveals that in nationalized contexts the impact of the rightleft party support is higher than in territorialized contexts. In cleavage theory, it could be interpreted as the nationalization of party system results in cleavages and polarization turn from the territorial to functional axis. However, conflict nature of politics and the existence of division lines remain essential for political mobilization.

Political beliefs and electoral preferences in Ukraine are broadly interpreted in terms of regional divisions (Barrington \& Herron, 2004; Birch, 2000; Craumer \& Clem, 1999; Katchanovski, 2006, 2014; Khmelko, Semenova, Teleshun, \& Titarenko, 2011; O'Loughlin, 2001; O'Loughlin, Toal, \& Kolosov, 2016), which also often include mentions of polarization (D'anieri, 2007; Kubicek, 2000; Kudelia, 2014; Sasse \& Lackner, 2018; Braychevsky, 2012; Shyshatskyi, 2006) and cleavages (Barrington, 1997, 2002; Dawson, 1997; Katchanovski, 2006; Malanchuk, 2005; Zimmerman, 1998). These studies often are limited to the artificial construction of regions and compositional effects, which do not reveal the whole spatiality of political beliefs in Ukraine. The issue of the territorial homogenization of electorate in Ukraine during the independence years is not revealed. The opposite process, territorial polarization, should also be examined in more details and its dynamics. Despite focus on such narrow issue as territorial polarization and homogenization, the paper also accentuates that geographical theory developments, especially debates on the scale, politics of scale, place, territory, and networks use in geographical studies, have a great potential to be used for the better understanding of the complexity of the spatiality of political beliefs in Ukraine.

Literature review. In this section of the paper, we want to discuss recent debates on the scale, territory, and place concepts use in geographical research and their potential use in the interpretation of elections results and territorial polarization. Agnew (1997; 2002; Shin \& Agnew, 2008) case study of Italy reveals how political parties use different geographical scales in their rhetoric, divide and structure territory of the country, and mobilize people in different local contexts. He assumes that geography is not external to political parties but inscribed in party politics and organization (Agnew, 1997). Agnew introduces politics of scale concept to electoral geography studies and argues that political parties in their rhetoric and organization are the main actors in the politics of scale. However, Brenner 
(2001, p. 602) is critical of such use of the scale concept stating that Agnew's case study which demonstrates scalar effects could not be narrowed only to scale and reveals complex spatialities of political processes, politics of location, and politics of territorial identity. As a result of the continuing debate on scale concept use in geography, Jessop, Brenner, and Jones, (2008) propose the TPSN framework (Territory, Place, Scale, Network). They argue that sociospatial relations should be understood as mutually constitutive and relationally intertwined dimensions of territories, places, scales, and networks because any singular of that dimensions cannot grasp the whole complexity of sociospatial processes (Jessop et al., 2008). Each of these four dimensions has its principle of sociospatial structuration: territory - bordering and enclosure, place - proximity, areal differentiation, and spatial embedding, scale - hierarchization and vertical differentiation, networks - interconnectivity and interdependence (Jessop et al., 2008, p. 393). The example of how place and scale are intertwined and mutually constitutive in electoral geography studies could be found in Johnston and his Colleagues (2005) study of neighborhood effect in Great Britain. They state that neighborhood effect operates at two levels: (1) level of social interactions in a locale, (2) level of a broader context, which also includes effects of local media and common agenda (Johnston et al., 2005). Agnew and Shin (2008) also show how messages at national level receive different local responses, which could be a result of the mediation role of party organization or place-specific factors.

Ukrainian electoral geography research is mainly limited to the regional level and does not problematize local contexts or scalar effects. We argue that scale and place are also essential for the better interpretation of electoral behavior in Ukraine. Swyngedouw (2001) in his political economy studies assumes that "place matters, but scale decides", which also could be applied to electoral geography studies. MacKinnon (2011) pointed out (proposing to replace "politics of scale" concept with "scalar politics") that different political actors can deploy scale strategically. Parties are such actors as was revealed by Agnew (1997; 2002). Moreover, geographical generalizations can influence political parties decisions how and where to campaign (in Johnston, Shelley, \& Taylor, 1990, p. 228). For instance, the vision of one of the scales as essential for the electoral campaign success by political leaders or their consultants can shape the electoral geography of the country. At the same time, parties have limited resources for the organization and how they deploy them have a geographical component. There is also a problem understanding scale just as a level of analysis. For instance, Barrington and Herron (2004) applied two, four, and eight regions model for the analysis of compositional characteristics impact on electoral preferences in Ukraine and found that language was a statistically significant factor only in the case of 2 regions. In such and other cases, scale effect could be understood in Smith (1992) terms as a mediation between homogeneity and difference.

Data and Methodology. The paper is based on cartographical analysis of electoral outcomes at polling stations level at 2002-2014 parliamentary elections (only proportional vote in case of mixed electoral systems in 2002,2012 , and 2014). The period of analysis is limited to 2002-2014 because there is no data at polling stations level for parliamentary elections of 1994 and 1998 in Ukraine, which complicates the analysis of electoral preferences dynamics at the local level. To analyze territorial homogenization, we followed Caramani (2002) methodological remarks and applied the analysis of variance using mean absolute deviation divided by two to avoid double counting also known as Lee index (Lee, 1988). It means that we took the sum of each party share deviation from the national average and divided it by two for each polling station in Ukraine. Then we calculated average Lee indexes for each parliamentary elections in 2002-2014 for Ukraine and separately for oblasts to reveal regional variations in the dynamics of territorial homogenization. Data for 2014 parliamentary elections is without polling stations in annexed by Russia Crimea and uncontrolled by Ukrainian government territories in Lugansk and Donetsk oblasts. We also mapped Lee indexes and analyzed the territorial distribution of polling stations with the highest deviations from the national average.

Results and discussion. Lee indexes for parliamentary elections 2002-2014 (divided by 100 for calculations purposes) calculated at polling stations level reveal gradual territorial homogenization of Ukraine from $2002(0.42)$ to $2014(0.28)$ (see Table 1). At the same time, the country was facing territorial polarization because despite the decrease in national average mean absolute deviations, three Galician oblasts had a permanently high level of polarization in 2002-2012, and Donbas oblasts also had high Lee indexes in 2002-2014. Regional dynamics in comparison to national shows that Galicia was polarized in 2002 in contrast to other regions of Ukraine, while 20062012 period was characterized by two poles territorial polarization, while at the national level territorial homogenization increased. In 2014 parliamentary elections, Galician oblasts homogenized to national mean, while Donbas oblasts remained polarized.

Table 1. Mean absolute deviation divided by two for Ukraine and Donetsk and Lviv oblasts for parliamentary elections 2002-2014 calculated at polling stations level

\begin{tabular}{lrrrrr} 
& Elections 2002 & Elections 2006 & Elections 2007 & Elections 2012 & Elections 2014 \\
\hline Ukraine & 0.42 & 0.37 & 0.29 & 0.29 & 0.28 \\
Donbas & 0.42 & 0.49 & 0.49 & 0.43 & 0.48 \\
Galicia & 0.55 & 0.50 & 0.48 & 0.41 & 0.29
\end{tabular}

Maps of polling stations with Lee indexes above 40 (high level of territorial polarization) reveal additional features how Ukraine was structured by political parties in 2002-2014 parliamentary elections (see Figure 1). First, in the 2002-2007 border of the territories with high deviation from the national mean in Western Ukraine followed the interwar border between USSR and Poland. Territories, which were under Polish rule voted more for nationaldemocratic parties in this period and were in opposition to Communists and Party of Regions, which was perceived as
pro-Russian. In 2012 elections, we see a turn in this part of the country. Volhynia region (Volyn and Rivne oblast and the northern part of the Ternopil oblast) homogenized with the national average, while Galicia remained highly polarized. Such turn was also accompanied by Party of Regions higher shares in Western Ukraine and Central Ukraine and nationalist Svoboda party high support in Galicia. Manafort case documents revealed by the United States court (letters and policy memos for Party of Regions leaders containing electoral strategy, advertising, and 
media campaigns) are great examples of how political actors deploy geographical scale strategically. 2012 elections success of the Party of Regions and shown on the map turn of polling stations at Central and Western Ukraine from the higher support of national-democratic parties to average in Ukraine might be interpreted by Manafort's strategic deployment of local scale into the national electoral campaign. His policy memos reveal that he accentuated gap between population expectations after the Orange revolution and years of Orange leaders in power and real conditions that could be experienced locally. Consequently, he proposed that campaign should include the idea of the local-national alliance for change and reorganization of the party to develop stronger regional and local presence. Polyakova (2014) case study of how nationalist Svoboda mobilized Galicia in 2012 parliamentary elections also reveals employment of local scale into national politics. Moreover, it is about the network of organizations, meetings, camps, support of local grassroots activities, which created a regional network of active people, which also was partially spread to the cities in other parts of Ukraine despite South-East of the country.
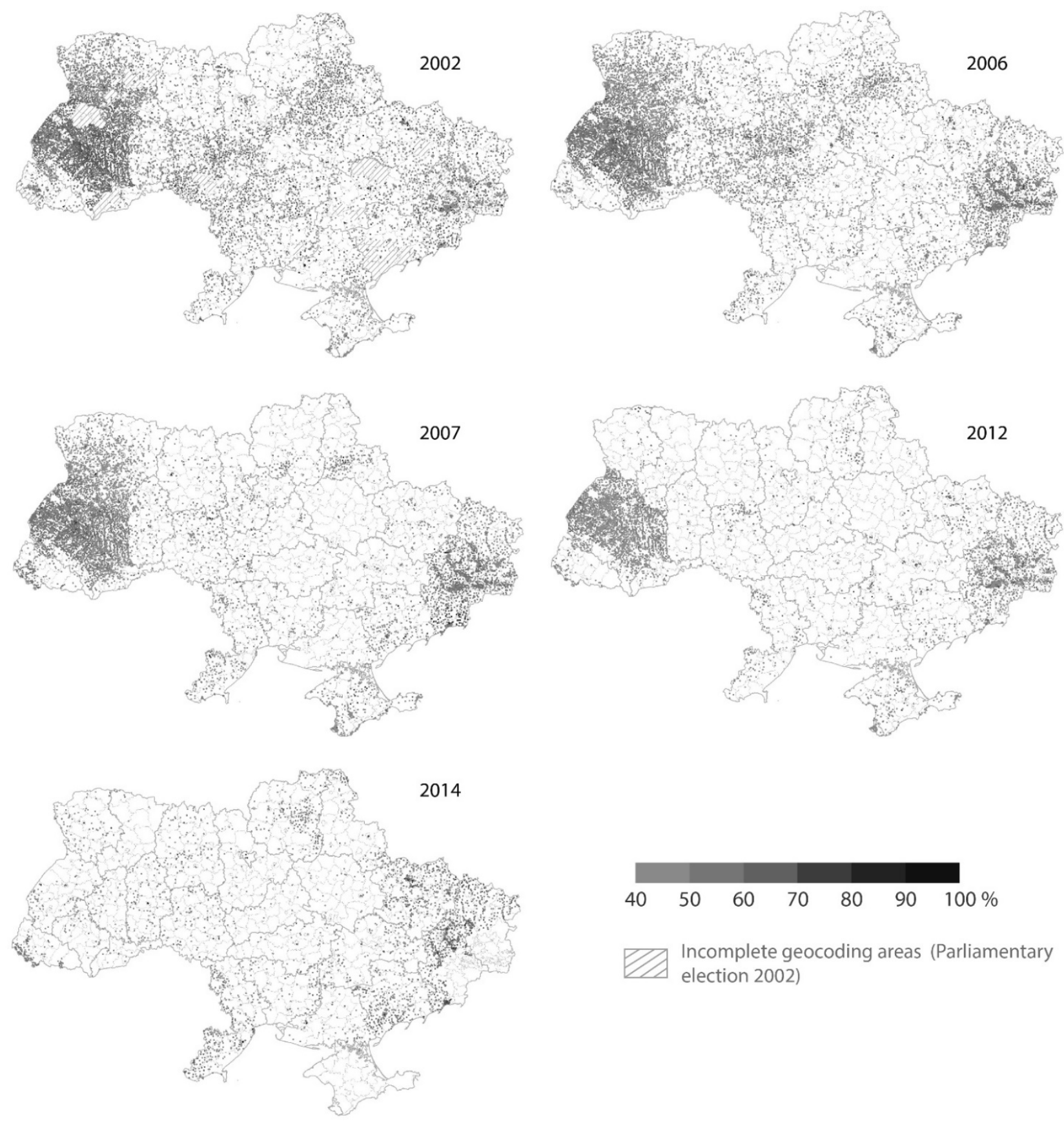

Figure 1. Deviation from the average in Ukraine electoral outcomes in parliamentary elections 2002-2014 at the polling station level (mean absolute deviation divided by two)

In 2014, Galicia demonstrated average Ukrainian mean absolute deviation (see Figure 1), while Donbass oblasts territories, which remained under the control of the Ukrainian government, continued to be polarized.
Moreover, 2006-2014 territorial polarization vividly follows administrative borders in the East of the country. We should mention that industrial Donbas area is not bounded by contemporary administrative divisions, while electoral 
preferences polarization follows boundaries of Donetsk and Lugansk oblasts. It shows the power of administrative elites in the mobilization of the electorate and the role of administrative resource control. Donetsk and Lugansk oblasts did not vote all the time similarly. For example, in 1999 presidential elections Donetsk oblast gave stronger support for Leonid Kuchma, while Lugansk oblast voted for Communists candidate, Petro Symonenko. In 2002 parliamentary elections, Donetsk oblast was efficiently mobilized by "Za Yedynu Ukrainu" (For United Ukraine), while Lugansk oblast remained aligned with Communists. After 2004 Orange revolution Party of Regions strategy was to unite all the businesses and local authorities who were afraid of the government changes after Orange revolution, which resulted in an alliance of predominantly South-East Ukraine administrative elites and local businesses opposed to Orange coalition. The rhetoric of the Party became vividly geographically scaled on the East-West divide constantly appealing to language and Russian questions. However, the elements of such scalar politics were also present in previous elections, but only after the Orange revolution cleavage line became more vivid and territorially structured. For instance, in the 2002 electoral campaign, Ukrainian TV was broadcasting political advertisement where the image of the map of Ukraine appeared. It was depicting three bordered from West to East territorial units, which were described as "three kinds of Ukrainians" appealing to "true Ukrainians" in the West, "hybrid Russified Ukrainians" in the Center, and "corrupted Ukrainians in the East". Geographical scale rhetoric was used here for the mobilization based on negative emotions (mobilization against East as a citizens "of lower quality" and was drawing clear lines between imagined "Us" and "Them" geographically).

Cartographic analysis also reveals that territories with higher shares of ethnic minorities are more territorially polarized. It should be cautiously treated and need further research for interpretation. Our study shows that it is not strictly following local distribution of ethnic minorities but is bounded by administrative borders at rayon level. At the same time, rayons where national minorities according to 2001 Census were composing majority of the rayon's population (Beregivskyi rayon and Beregovo city in Zakarpattya, Gertsaivskyi rayon in Chernivtsi, Putyvlskyi rayon in Sumy, Bolgradskyi, Artsyzkyi, Reniyskyi, Tarutynskyi, and Izmailskyi in Odesa oblast) are highly polarized in contrast to rayons where share of national minorities is lower than 50 percent but still essential (higher than $10 \%$ ), which demonstrate various electoral behavior patterns. Moreover, we should admit that high Lee index is not obviously about territorial polarization but may reveal spatial heterogeneity and local variations in party support. Such local variations (clusters of spatially concentrated polling stations with high deviation from the national mean) may be interpreted as unique places for further research of local contexts effects and local manifestations of party and electoral campaign organization.

Conclusion. While parliamentary elections 2002-2014 reveal continually increasing territorial homogenization of voting behavior in Ukraine, it was accompanied by territorial polarization in three Galician oblasts and two Donbas oblasts. In 2002, Galician oblasts were the only pole to national mean, while the rest of the country also demonstrated high territorial heterogeneity. After the Orange revolution territory of the country was continually territorially homogenized despite rhetorical and media polarization, while the two poles structure (Galicia and Donbas) is revealed in 2006-2012 elections. Moreover, in 2012, Galicia pole was following historical border of
Austrian empire instead of contemporary administrative borders (northern part of Ternopil oblasts became less polarized and voted closer to average national mean). Volhynia region also demonstrated turn to national average in 2012, which diminished previously essential line of interwar border between Poland and USSR. It might be interpreted by strategic change of scalar politics by Party of Regions and scalar reorganization of the Party, which could be found at Manafort trial court documents. Case studies of nationalist Svoboda party mobilization of Galicia region (Polyakova, 2014) reveal the role of local networks and local organization of electoral campaigns effects (also scalar effects). In 2014 elections, Galicia was territorially homogenized to national mean, while Donetsk and Lugansk oblasts territories under the control of Ukrainian government remained polarized as well as high level of polarization remained in administratively bounded territories, ehre ethnic minorities constitute majority of the population.

The TPSN framework is useful for the interpretation of such patterns of electoral behavior in Ukraine. First, territory as a bounded area is essential both in case of voting behavior strictly following administrative boundaries and manifestations of historical borders (interwar border between USSR and Poland in 2002-2007 and border between Austrian and Russian empires in case of Galicia 2012). However, the interpretation of the influence of contemporary administrative boundaries as well as historical borders need further research. Second, place is essential because we can find many local variations, which do not follow regional patterns within contemporary administrative or phantom borders as well as local contexts are essential for the response to political messages at all the levels and are elements of parties' organization. Our study reveals that scale is also essential for the understanding of territorial patterns of voting in Ukraine and political parties strategic deployment of scale can change electoral geography of the country (Party of Regions strategic local-national alliance for Western and Central Ukraine oblasts in preparation for 2012 elections revealed by Manafort case documents). Moreover, all the mentioned dimensions of the interpretation of voting behavior have networks effects, which include party localregional-national networks creation as well as social connections importance for neighborhood effect use by political parties (demonstrated by Polyakova case study of Svoboda electoral campaign in Galicia in 2012). Therefore, spatiality of electoral results in Ukraine is a mix of scalar, territorial, place, and networks effects on voting behavior in the country and parties have a mediation role connecting local and national contexts.

References:

1. Braychevskyy, Yu. S. Problems of Regional Polarization of SocialPolitical Development of Ukraine in Foreign Literature. Geography and Tourism, no. 22, 2012, pp. 233-40. (Originally - in Ukrainian language).

2. Shyshatskyi, V. B. Electoral-geographic polarization in Ukraine as factor of regional destabilization of the country. Bulletin of Taras Shevchenko National University of Kyiv (Geography), no. 53, 2006, pp. 27 30. (Originally - in Ukrainian language).

3. Agnew, John. The Dramaturgy of Horizons : Geographical Scale in the 'Recconstruction of Italy' by the New Italian Political Parties, 1992-95. Political Geography, vol. 16, no. 2, 1997, pp. 99-121.

4. Agnew, John. Place and Politics in Modern Italy. The University of Chicago Press, 2002

5. Bail, Christopher A., et al. Exposure to Opposing Views on Social Media Can Increase Political Polarization. Proceedings of the National Academy of Sciences of the United States of America, vol. 115, no. 37 National Academy of Sciences, Sept 2018, pp. 9216-21, doi:10.1073/pnas.1804840115.

6. Barrington, Lowell W. Examining Rival Theories of Demographic Influences on Political Support : The Power of Regional, Ethnic, and Linguistic Divisions in Ukraine. European Journal of Political Research, vol. 41, 2002, pp. 455-91, doi:10.1111/1475-6765.00019.

7. Barrington, Lowell W. The Geographic Component of Mass Attitudes in Ukraine. Post-Soviet Geography and Economics, vol. 38, no. 10, 1997, pp. 601-14, doi:10.1080/10889388.1997.10641065. 
8. Barrington, Lowell W., and Erik S. Herron. One Ukraine or Many ? Regionalism in Ukraine and Its Political Consequences. Nationalities Papers, vol. 32, no. 1, 2004, pp. 53-86, doi:10.1080/ 0090599042000186179

9. Bernhardt, Dan, et al. Political Polarization and the Electoral Effects of Media Bias. Journal of Public Economics, vol. 92, no. 5-6, NorthHolland, June 2008, pp 1092-104, doi:10.1016/J JPUBEC0.2008.01.006.

10. Birch, Sarah. Interpreting the Regional Effect in Ukrainian Politics. Europe-Asia Studies, vol. 52, no. 6, 2000, pp. 1017-41, doi:10.1080/09668130050143815

11. Brenner, Neil. The Limits to Scale ? Methodological Reflections on Scalar Structuration. Progress in Human Geography, vol. 25, no. 4, Sage PublicationsSage CA: Thousand Oaks, CA, Dec. 2001, pp. 591-614, doi:10.1191/030913201682688959.

12. Caramani, Daniele The Measurement of Territorial Homogeneity: A Test on Comparative Electoral Data since 1832. 2002, http://cadmus.eui.eu/ bitstream/handle/1814/1784/02_26.pdf?sequence=1.

13. Craumer, Peter R., and James I. Clem Ukraine's Emerging Electoral Geography: A Regional Analysis of the 1998 Parliamentary Elections. Post-Soviet Geography and Economics, vol. 40, no. 1, 1999 , pp. 1-26, doi:10.1080/10889388.1999.10641097.

14. D'anieri, Paul. Ethnic Tensions and State Strategies Understanding the Survival of the Ukrainian State. Journal of Communist Studies and Transition Politics, vol. 23, no. 1, 2007, pp. 4-29, doi:10.1080/13523270701194896

15. Dawson, Jane I. Ethnicity, Ideology and Geopolitics in Crimea. Communist and Post-Communist Studies, vol. 30, no. 4, Pergamon, Dec. 1997, pp. 427-44, doi:10.1016/S0967-067X(97)00013-5

16. Ferreira Do Vale, Helder. Territorial Polarization in Brazil's 2014 Presidential Elections. Regional \& Federal Studies, vol. 25, no. 3, Routledge, May 2015, pp. 297-311, doi:10.1080/13597566.2015.1060964.

17. Jessop, Bob, et al. Theorizing Sociospatial Relations. Environment and Planning D: Society and Space, vol. 26, no. 3, 2008, pp. 389-401, doi:10.1068/d9107.

18. Johnston, R. J., et al., editors. Developments in Electoral Geography. Routledge, 1990.

19. Johnston, Ron, Kelvyn Jones, et al. Party Support and the Neighbourhood Effect : Spatial Polarisation of the British Electorate, 19912001. Political Geography, vol. 23, no. 4, 2004, pp. 367-402, doi:10.1016/j.polgeo.2003.12.008.

20. Johnston, Ron, Carol Propper, et al. Spatial Scale and the Neighbourhood Effect : Multinomial Models of Voting at Two Recent British General Elections. British Journal of Political Science, vol. 35, no. 3, Cambridge University Press, July 2005, pp. 487-514, doi:10.1017/ S0007123405000268

21. Katchanovski, Ivan. East or West ? Regional Political Divisions in Ukraine since the 'Orange Revolution' and the 'Euromaidan.' American Political Science Association, 2014, p. 43, doi:10.1017/ CBO9781107415324.004.

22. Regional Political Divisions in Ukraine in 1991-2006. Nationalities Papers, vol. 34, no. 5, 2006, pp. 507-32, doi:10.1080/00905990600952939.

23. Khmelko, Irina S., et al. Regionalism in Ukraine and Its Role in the Ukrainian Politics. Journal of East European and Asian Studies, vol. February, 2011, pp. 93-110.

24. Kubicek Paul Regional Polarisation in Ukraine: Public Opinion Voting and Legislative Behaviour. Europe-Asia Studies, vol. 52. March 2015, 2000, pp. 273-94, doi:10.1080/09668130050006790.
25. Kudelia, Serhiy The House That Yanukovych Built. Journal of Democracy, vol. 25, no. 3, 2014, pp. 19-34, doi:10.1353/jod.2014.0039.

26. Lee, Adrian. The Persistence of Difference: Electoral Change in Cornwall. Political Studies Association Conference, Plymouth, 1988.

27. Lipset, Seymour Martin, and Stein Rokkan Cleavage Structures, Party Systems, and Voter Alignments : An Introduction. Party Systems and Voter Alignments; Cross-National Perspectives, 1967, pp. 1-50.

28. MacKinnon, Danny Reconstructing Scale : Towards a New Scalar Politics. Progress in Human Geography, vol. 35, no. 1, SAGE PublicationsSage UK: London, England, Feb. 2011, pp. 21-36, doi:10.1177/0309132510367841.

29. Maggini, Nicola, and Vincenzo Emanuele Contextual Effects on Individual Voting Behaviour: The Impact of Party System Nationalization in Europe. Italian Political Science Review/Rivista Italiana Di Scienza Politica, vol. 45, 2015, pp. 105-30, doi:10.1017/ipo.2015.7.

30. Malanchuk, Oksana Social Identification versus Regionalism in Contemporary Ukraine. Nationalities Papers, vol. 33, no. 3, 2005, pp. 34568, doi:10.1080/00905990500193204.

31. McAllister, lan, and Donley T. Studlar Region and Voting in Britain, 1979-87 : Territorial Polarization or Artifact ? American Journal of Political Science, vol. 36, no. 1, Midwest Political Science Association, Feb. 1992, p. 168, doi:10.2307/2111429.

32. O'Loughlin, J. The Regional Factor in Contemporary Ukrainian Politics : Scale, Place, Space, or Bogus Effect ? Post-Soviet Geography and Economics, vol. 42, 2001, pp. 1-33, doi:10.1080/10889388.2001.10641161.

33. O'Loughlin, John, et al. Who Identifies with the 'Russian World' ? Geopolitical Attitudes in Southeastern Ukraine, Crimea, Abkhazia, South Ossetia, and Transnistria. Eurasian Geography and Economics, vol. 57. no. 6, Routledge, 2016, pp. 745-78, doi:10.1080/15387216.2017.1295275.

34. Polyakova, Alina From the Provinces to the Parliament: How the Ukrainian Radical Right Mobilized in Galicia. Communist and PostCommunist Studies, vol. 47, no. 2, Elsevier Ltd, 2014, pp. 211-25, doi:10.1016/j.postcomstud.2014.04.012.

35. Prior, Markus Media and Political Polarization. Annual Review of Political Science, vol. 16, no. 1, Annual Reviews, May 2013, pp. 101-27, doi:10.1146/annurev-polisci-100711-135242.

36. Sasse, Gwendolyn, and Alice Lackner War and Identity: The Case of the Donbas in Ukraine. Post-Soviet Affairs, vol 34, no. 2-3, Routledge, May 2018, pp. 139-57, doi:10.1080/1060586X.2018.1452209.

37. Shin, Michael E., and John A. Agnew Berlusconi's Italy : Mapping Contemporary Italian Politics. Temple University Press, 2008.

38. Smith, Nei. Geography, Difference and the Politics of Scale. Postmodernism and the Social Sciences, 1992, pp. 57-79, doi:10.1007/9781-349-22183-7 4

39. Swyngedouw, Erik Scaled Geographies Nature, Place, and the Politics of Scale. 2001, http://courseresources.mit.usf.edu/sgs/ang6469/ canvas/module 3/read/Swyngedouw-case2.pdf.

40. Tucker, Joshua, et al. Social Media, Political Polarization, and Political Disinformation : A Review of the Scientific Literature. SSRN Electronic Journal, Mar. 2018, doi:10.2139/ssrn.3144139.

41. Wing, lan Sue, and Joan L. Walker The Geographic Dimensions of Electoral Polarization in the 2004 U.S. Presidential Vote. Springer, Berlin, Heidelberg, 2010, pp. 253-85, doi:10.1007/978-3-642-03326-1_13.

42. Zimmerman, William Is Ukraine a Political Community? Communist and Post-Communist Studies, vol. 31, no. 1, 1998, pp. 43-55, doi:10.1016/S0967-067X(97)00022-6

Надійшла до редколегії 09.10.18

М.Добиш, асп.

Київський національний університет імені Тараса Шевченка, Київ, Україна

\section{ПОЛІТИКА МАСШТАБУ ТА ТЕРИТОРІАЛЬНА ПОЛЯРИЗАЦІЯ ЕЛЕКТОРАЛЬНИХ УПОДОБАНЬ В УКРАЇНІ, 2002-2014}

Націоналізація партійної системи та електорату не обов'язково виливається у територіальну гомогенізацію електоральної поведінки і переходу від територіальних до функціональних розломів. Результати виборів в Україні широко аналізуються із перспективи регіональних відмінностей, ефекту структури населення, розломів та поляризації політичних поглядів. Однак, ми вважаємо, що просторовість електоральної поведінки в Україні є більш складною і може бути краще зрозуміла, використовуючи модель TPSN - переплетений та взаємоважливий ефект території (T), географічного місия (P), географічного маситабу (S) та мереж (N). Стаття має за мету аналіз територіальної гомогенізації, гетерогенності та поляризації електоральної поведінки в Україні, використовуючи дані на рівні виборчих дільниць для парламентських виборів 2002-2014 рр. Ми використовуємо індекс Лі для аналізу територіальної гомогенізації (аналіз варіації на основі середнього абсолютного відхилення поділеного на два з метою уникнення подвійного підрахунку). Дослідження показує, що у 2002-2014 рр. електоральна поведінка в Украӥні поступово і постійно територіально гомогенізувалася і водночас територіально поляризувалася - індекс для країни в цілому знижувався (збільшення гомогенності), тоді як для окремих регіонів він зростав або стабільно залишався високим (зокрема для Галичини та Донбасу). У 2002 р. він був для Галицьких областей відчутно вищим, ніж для всієї іншої території України, тоді як у 2006-2012 рр. установилася двополюсна структура зі стабільно високою поляризацією між Донбасом і Галичиною та зростаючою гомогенністю голосування в інших регіонах із локальними відхиленнями. Картографічний аналіз також показує важливість адміністративних кордонів (часто поведінка виборців наслідує саме їх) та часом історичних кордонів (у 2002-2007 рр. міжвоєнного кордону між Польщею і СРСР та у 2012 р. кордону між Австрійською й Російською імперіями на півночі сучасної Тернопільської області). Більше того, оприлюднені документи судової справи проти Манафорта показують, як географічний маситаб стратегічно використовувався Партією регіонів, а існуючі дослідження вказують на ефективне використання мереж для мобілізачії Галичини у 2012 р. Хоча наше дослідження емпірично дуже обмежене, але воно вказує на взаємодоповнюючий ефект території як обмеженого кордонами ареалу, місця як контексту, географічного маситабу як стратегічного політичного інструменту та організаційних рамок для партій і мереж, як суттєвих для кращого розуміння того, як партії структурують територію України.

Ключові слова: територіальна гомогенізація, територіальна поляризація, політика географічного маситабу, парламентські вибори в Україні. 
Н. Добыш, асп.

Киевский национальный университет имени Тараса Шевченко, Киев, Украина

\section{ПОЛИТИКА МАСШТАБА И ТЕРРИТОРИАЛЬНАЯ ПОЛЯРИЗАЦИЯ \\ ЭЛЕКТОРАЛЬНЫХ ПРЕФЕРЕНЦИЙ В УКРАИНЕ, 2002-2014}

Статья исследует территориальную гомогенизацию и поляризацию в Украине на примере парламентских выборов в 2002 2014 ге. Для исследования используются данные на уровне участков для голосования и индекс Ли для анализа территориальной гомогенизации (анализ вариации на основе среднего абсолютного отклонения, поделенного на два для избегания двойного подсчета). Результаты показывают, что, в то время как электоральное поведения в Украине в 2002-2014 г2. становилось все больше территориально гомогенизированным (индекс Ли постепенно снижался), страна переживала территориальную поляризацию, поскольку показатель для трех Галицких областей и двух Донбасских рос или стабильно оставался высоким. Больше того, если в 2002 г. территориальная структура показывала значимую территориальную гетерогенность и только Галицкие области как полюс, то в $2006-2012$ г2. структура стала биполярной. В 2014 г. Западный полюс относительно территориально гомогенизировался, тогда как территории Донецкой и Луганской областей остались территориальным полюсом. Такие документы, как раскрытые следствием в суде против Манафорта, показывают, что такая динамика имеет аспект стратегического использования географического маситаба для достижения электорального успеха Партией регионов. Также статья обращает внимание на важность административных и исторических границ, которым часто следует электоральное поведение.

Ключевые слова: территориальная гомогенизация, территориальная поляризация, политика географического маситаба, парламентские выборы в Украине.

http://doi.org/10.17721/1728-2721.2019.73.13

УДК 911.3:33(477.8)

М. Ярошевич, асп.

Львівський національний університет імені Івана Франка, Львів, України

\section{ТРАНСПОРТНО-ГЕОГРАФІЧНЕ ПОЛОЖЕННЯ ЯК ЧИННИК ФОРМУВАННЯ СХІДНОЄВРОПЕЙСЬКОГО ГАЗОВОГО ХАБУ}

Східноєвропейський газовий хаб - один із найбільш масштабних енергетичних проектів, який здатен лібералізувати ринок природного газу, інтегрувати украйнську газотранспортну систему в загальноєвропейську систему газопроводів та забезпечити рентабельність підземних сховищ газу країни. Розглянуто географічне положення як важливий фактор формування Східноєвропейського газового хабу. Охарактеризовано один із основних об'єктів газотранспортної інфраструктури - газові сховища, на базі яких має сформуватись майбутній український газовий хаб. Проаналізовано основні параметри функціонування газових сховищ. Вивчено європейський досвід функціонування газових хабів. Проведено аналіз функціонування газових хабів Німеччини та їх зв'язок із газосховищами країни.

Ключові слова: географічне положення, суспільно-географічне положення, економіко-географічне положення, газовий хаб, газове сховище

Постановка проблеми. Географічна віддаленість газосховищ Західного регіону України (ЗРУ) від інших підземних сховищ газу (ПСГ) країни не тільки зміцнює логістичні позиції, але й також дає змогу розглядати сукупність ПСГ ЗРУ як газовий хаб європейського зразка. Тобто, мова може йти про формування на території ЗРУ Східноєвропейського газового хабу. Актуальність теми дослідження полягає у необхідності суспільногеографрічного вивчення транспортно-енергетичних проблем країни. Найбільшою мірою у цій праці використовуються конкретно наукові методи, а саме: метод аналізу аналогових ареалів, оскільки проводиться дослідження об'єктів - газових хабів шляхом їх зіставлення; метод порівняння; картографрічний метод (для наочного висвітлення досліджуваної проблематики).

Аналіз останніх досліджень і публікацій. Поняття географічного положення $є$ однією з головних категорій географрічної науки. Під ним розуміють розташування об'єкта або ареалу земної поверхні стосовно інших об'єктів чи територій, які розміщені за межами цього об'єкта або ареалу і мають на них вплив. Географічне положення - динамічний опис, який постійно набуває нових ознак і змінюється у міру зміни різних властивостей географрічного об'єкта та його взаємозв'язків з іншими об'єктами і явищами. Проф. О. Шаблій зазначає, що "географрічне положення - це просторове відношення певного об'єкта (країни, міста, гірського масиву тощо) до географічних данностей, що лежать поза ним і мають чи можуть мати на нього суттєвий вплив" [5, с. 93]. У структурі географрічного положення виділяють підсистеми - суспільно-економічне, культурно-географрічне, етнокультурно-географічне положення. Учений відносить "географрічне положення" до складної категорії, оскільки воно завжди індивідуалізує географрічний об'єкт. У "географічному положенні" відображається така його ознака, як позиційність і унікальність. На думку вченого, географрічне положення - це властивість об'єкта, але водночас у ньому відображається його відношення до інших територіальних систем. Підхід до визначення суспільно-географрічного положення цілком зберігає риси визначення географрічного положення як такого. Суспільно-географрічне положення трактується як положення певного суспільно-географічного об'єкта щодо інших об'єктів, які мають для нього господарське значення (джерел сировини та енергії, транспортних шляхів тощо). Проф. О. Топчієв у праці "Основи суспільної географії" описує відношення та взаємодію географрічного об'єкта з іншими об'єктами як важливу характеристику, яка впливає на його подальший розвиток. Учений зазначає, що просторове відношення об'єкта до інших сусідніх $€$ відносною прив'язкою, але використовується географами частіше, оскільки дає змогу здійснити комплексну характеристику просторової організації: "...теорія і практика суспільно-географрічних досліджень переконливо свідчать, що саме аналіз відносних місцеположень, дослідження сусідства дають змогу дати розміщенню окремих об'єктів глибоку та змістовну якісну характеристику" [2, с. 154-155]. $€$ кілька наукових праць, які розглядають тему газових хабів. Праця П. Хезера "Континентальні європейські газові хаби: чи виконують вони поставлені цілі?" забезпечує загальний огляд розвитку газового ринку Європи. Після вивчення розвитку торговельної ліквідності та тісного взаємозв'язку газових хабів можна стверджувати про швидке наростання потужностей газових хабів [3]. Ця праця також дає уявлення про особливості окремих вузлів, причини їх конкретного еволюційного шляху та перспективи їх подальшого розвитку.

Мета. Метою роботи є висвітлення важливих географрічних передумов формування проектованого Схід- 